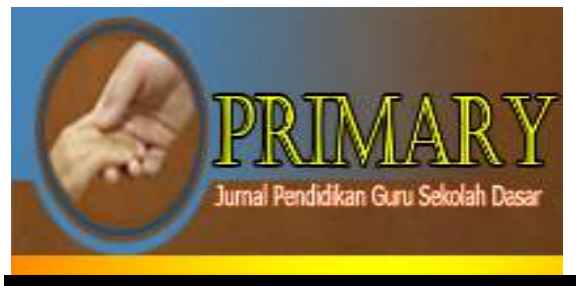

\author{
PRIMARY: JURNAL PENDIDIKAN GURU SEKOLAH DASAR \\ VOLUME 10 NOMOR 5 OKTOBER 2021 \\ ISSN : 2303-1514 | E-ISSN : 2598-5949 \\ DOI : http://dx.doi.org/10.33578/jpfkip.v10i5.8234 \\ https://primary.ejournal.unri.ac.id/index.php/JPFKIP
}

\title{
AGAMI MEDIA FOR THEMATIC LEARNING AT GRADE III OF ELEMENTARY SCHOOL
}

\author{
Remanda Wahyu Intansari ${ }^{1}$, Marinda Sari Sofiyana ${ }^{2}$, Mar'atus Sholihah ${ }^{3}$ \\ ${ }_{1,2,3}$ Universitas Islam Balitar, Blitar, Indonesia \\ remandawahyu85@gmail.com, ${ }^{2}$ sarisofiyana@gmail.com, ${ }^{3}$ maratussholihah11292@gmail.com
}

MEDIA AGAMI UNTUK PEMBELAJARAN TEMATIK SISWA KELAS III SD

\begin{tabular}{|c|c|}
\hline ARTICLE HISTORY & ABSTRACT \\
\hline $\begin{array}{l}\text { Submitted: } \\
13 \text { Februari } 2021 \\
13^{\text {th }} \text { February } 2021\end{array}$ & $\begin{array}{l}\text { Abstract: The problems obtained from the preliminary study indicated that there was no } \\
\text { learning media for thematic learning for "Kenampakan Alam" material at grade III of } \\
\text { elementary school. The direction of research to develop Agami media became learning support } \\
\text { for grade III of elementary school, especially the theme of "Benda Disekitarku". This research } \\
\text { and development applied the Borg and Gall models. This research was carried out in seven } \\
\text { stages, namely potential and case, data accumulation, product design, design validation, } \\
\text { design revision, exhibition product, and product revision. The type of data was feasibility and } \\
\text { quality data of the media. The instrument was a validation questionnaire to calculate the } \\
\text { feasibility of the media and students' response to criterion quality of media. The subjects in this } \\
\text { study were } 12 \text { students at grade III of elementary school in Doko. The results of the validation } \\
\text { by three experts, namely a media expert, a material expert, and a linguist expert, obtained an } \\
\text { average of } 95.2 \% \text { with a feasible criterion. Then, the result of students' response got a score of } \\
93.75 \% \text { with a very feasible criterion and was suitable for third grade elementary school } \\
\text { students. The results from the validator's assessment and student responses found that Agami } \\
\text { media was feasible for thematic learning at grade III of elementary school. It is expected that } \\
\text { the Agami media can be further developed by the next researchers until the } 10 \text { stage of Borg } \\
\text { and Gall to achieve better educational goals and effectiveness in learning outcomes. }\end{array}$ \\
\hline
\end{tabular}

Accepted:

04 September 2021

Keywords: agami media, thematic learning

$04^{\text {th }}$ September 2021

\begin{abstract}
Abstrak: Permasalahan yang didapatkan dari studi pendahuluan menunjukkan bahwa belum terdapat media pembelajaran pada pembelajaran tematik untuk materi kenampakan alam kelas III SD. Tujuan penelitian ini untuk mengembangkan media Agami sebagai penunjang pembelajaran siswa kelas III SD khususnya tema benda di sekitarku. Jenis penelitian ini adalah penelitian dan pengembangan yang berpedoman pada model Borg dan Gall. Penelitian media Agami dilakukan sampai tujuh tahap yaitu potensi dan masalah, pengumpulan data, desain produk, validasi desain, revisi desain, uji coba produk, dan revisi produk. Jenis data diambil dari kelayakan dan kualitas media. Instrumen yang digunakan adalah angket validasi untuk mengukur kelayakan media dan respon siswa untuk mengukur kualitas media. Subjek dalam penelitian sejumlah 12 siswa kelas III SD di Kecamatan Doko. Hasil validasi dari ketiga ahli yaitu media, materi, dan bahasa mendapatkan skor sebesar 95.2\% dengan kriteria layak. Hasil respon siswa mendapatkan skor $93.75 \%$ dengan kriteria sangat layak dan sesuai dengan siswa kelas III SD. Berdasarkan hasil validasi media dan respon siswa maka disimpulkan bahwa media Agami layak digunakan untuk pembelajaran tematik siswa kelas III SD. Peneliti mengharapkan pada media Agami dapat dikembangkan lagi oleh para ahli berikutnya sampai tahap ke 10 dari Borg and Gall agar tercapai tujuan pendidikan yang semakin baik dan efektifitas dalam hasil belajar siswa.
\end{abstract}

Kata Kunci: media agami, pembelajaran tematik

\section{CITATION}

Intansari, R. W., Sofiyana, M. S., \& Sholihah, M. (2021). Agami Media for Thematic Learning at Grade III of Elementary School. Primary: Jurnal Pendidikan Guru Sekolah Dasar, 10 (5), 1079-1090. DOI: http://dx.doi.org/10.33578/jpfkip.v10i5.8234 


\section{PENDAHULUAN}

Kurikulum merupakan suatu gagasan sebagai program pembelajaran yang ditunjukkan dengan tindakan (Widiyatmono, 2014). Tingkat SD dan menengah saat ini menggunakan kurikulum 2013. Kurikulum 2013 adalah kurikulum berbasis kompetensi untuk pembelajaran konstruktivistik (Akbar, 2015). Berdasarkan kurikulum ini, pembelajaran khusus untuk siswa SD adalah pembelajaran tematik. Pembelajaran tematik merupakan cara belajar siswa secara individu maupun kelompok agar menjadi aktif dalam menggali ilmu melalui tema yang telah ditentukan (Akbar, 2015). Keterlaksanaan pembelajaran mengacu pada kurikulum competency based termasuk keterlaksanaan dalam pembelajaran tematik yang ditentukan dari kemampuan guru untuk mengembangkan perangkat pembelajaran dan media pembelajaran.

Media pembelajaran merupakan faktor yang dapat dijadikan penentu keberhasilan dalam pembelajaran. Media pembelajaran adalah sebuah alat penyalur informasi agar kondisi kelas dapat kondusif untuk menumbuhkan kegiatan belajar yang lebih baik (Asyhar, 2012). Peranan media pembelajaran dalam kegiatan belajar mengajar bukan untuk peranan tambahan, melainkan sebagai alat untuk membantu menghasilkan kondisi kelas yang efektif (Nana \& Ahmad, 2015). Pemanfaatan media diharapkan dapat meningkatkan prestasi belajar siswa.

Ketersediaan media pembelajaran merupakan faktor penting untuk kegiatan pembelajaran (Arsyad, 2014) namun yang terjadi di sekolah yaitu guru belum memiliki pengetahuan cukup tentang media yang tepat untuk digunakan dalam pembelajaran sedangkan ada sebagian materi yang harus diajarkan menggunakan media (Ramli, 2017). Penelitian yang dilakukan oleh Hendratni (2016) mengungkapkan bahwa kegiatan pembelajaran yang hanya ceramah dan tidak didukung media pembelajaran akan mengakibatkan siswa kurang memperhatikan pembelajaran. Kurangnya kreativitas guru dalam mengajar menggunakan media dan sumber belajar juga akan mempengaruhi perkembangan potensi siswa (Baharuddin, 2016). Keterbatasan media masih menjadi persoalan utama yang perlu diperhatikan karena pada kurikulum 2013 ini diharapkan semua guru harus mampu mengeksplorasi media menjadi bervariasi demi kelancaran pembelajaran (Ariyanti, 2015).

Hasil studi pendahuluan yang telah dilakukan pada tiga SD di Kabupaten Blitar yang tersebar di Kecamatan Talun, Kecamatan Nglegok, dan Kecamatan Doko diketahui bahwa metode mengajar pada pembelajaran tematik menggunakan metode ceramah dan bahan ajar pendukungnya yaitu buku guru tematik SD kelas III. Pada ketiga sekolah tersebut tidak ada media pembelajaran untuk materi tema benda di sekitarku. Siswa kesulitan menghubungkan konsep pada satu mata pelajaran dengan konsep pada mata pelajaran lainnya. Buku panduan guru hanya ada buku guru tematik SD kelas III sehingga kondisi ini menyebabkan siswa bosan dan kurang kreatif pada kegiatan belajar. Keterbatasan guru menjelaskan menyebabkan siswa kesulitan untuk menghubungkan antara pelajaran satu dengan yang lain.

Hasil angket tertutup yang diberikan pada siswa menunjukkan bahwa 64\% siswa menyatakan pembelajaran benda di sekitarku subtema keajaiban perubahan wujud di sekitarku merupakan materi yang sulit dipahami. Permasalahan yang dialami siswa yaitu saat pembelajaran perubahan wujud di sekitarku, siswa masih belum dapat menguasai materi yang disampaikan guru karena pada pembelajaran ini dibutuhkan penjelasan konkret. Siswa perlu mengamati peristiwa perubahan wujud benda secara konkret agar mudah menguasai materi. Namun faktanya belum ada media penunjang yang dapat membantu mengamati peristiwa perubahan wujud benda secara konkret di kelas sehingga menyebabkan siswa kesulitan untuk menguasai materi perubahan wujud benda. Kondisi ini 
harus segera diatasi agar kesulitan siswa dalam belajar tema benda di sekitarku dapat segera teratasi.

Salah satu cara yang dilakukan untuk membantu mengatasi kesulitan siswa dalam belajar tema benda di sekitarku yaitu mengembangkan media pembelajaran. Adapun media pembelajaran dikembangkan untuk memudahkan siswa mempelajari tema benda di sekitarku adalah media Agami. Media Agami (Alat Peraga Miniatur) adalah media tiga dimensi dengan pemandangan alam disertai dengan miniatur pendukung untuk perubahan wujud benda di sekitar yang terbuat dari barang-barang yang dibentuk seperti benda aslinya dan dapat diperagakan. Adanya media miniatur ini diharapkan akan mempermudah penyampaikan materi belajar dari guru karena siswa dapat mengamati benda dan memperagakan perubahan wujud benda secara konkret meskipun hanya dengan miniatur tiruan dari benda aslinya.

Media Agami memuat konsep untuk empat mata pelajaran yaitu Bahasa Indonesia, PPKn, PJOK, dan Matematika. Media Agami cocok digunakan dalam pembelajaran tematik karena didalamnya memuat empat konsep mata pelajaran yang dirangkai menjadi satu untuk memudahkan siswa mempelajari materi antar mata pelajaran. Selain itu, melalui media Agami siswa dapat mengamati benda-benda secara konkret melalui miniatur yang menyerupai benda aslinya. Hal ini sesuai dengan penelitian (Ramli, 2017) yang mengungkapkan bahwa miniatur sederhana berupa kenampakan alam menekankan pada siswa untuk lebih aktif dalam pembelajaran. Tujuan penelitian ini adalah mengembangkan media Agami sebagai penunjang pembelajaran siswa kelas III SD pada pembelajaran tematik khususnya tema benda di sekitarku.

\section{KAJIAN TEORI \\ Media Pembelajaran}

Media berasal dari bahasa latin yaitu medius mempunyai arti penyalur pembelajaran tematik (Arsyad, 2014). Media juga diartikan sebagai alat untuk menyalurkan segala petunjuk yang memberikan ketertarikan kepada siswa ketika proses pembelajaran tematik berlangsung (Komala et al., 2016). Media pembelajaran adalah benda yang digunakan untuk memberikan perintah agar dapat mendorong terjadinya proses belajar mengenai materi benda disekitarku yang ada di lingkungan (Miarso, 2004).

\section{Miniatur}

Salah satu jenis media pembelajaran adalah miniatur. Miniatur merupakan replika realitas yang digambarkan pada skala kecil yang dirangkai menjadi media tiga dimensi (Khairi, 2012). Kehidupan sehari-hari sering menggunakan media tiga dimensi berupa boneka dan model (Nana \& Ahmad, 2015). Boneka adalah model yang diperlihatkan untuk permainan sedangkan model adalah replika tiga dimensi yang digambarkan sebagai benda nyata (Nana \& Ahmad, 2015). Berbagai jenis media tiga dimensi dapat membantu menjelaskan tentang benda-benda di sekitar lingkungan yang digambarkan menjadi skala kecil untuk mempermudah pemahaman siswa dengan keadaan di lingkungan sekitar. Miniatur alam sekitar adalah media berupa gambaran kenampakan alam ukurannya lebih kecil dari aslinya (Anggraini, 2019). Media yang digunakan untuk menggambarkan bendabenda di sekitar lingkungan terbuat dari bahan utama yang tahan lama.

\section{Media Agami}

Bahan utama yang dipakai media Agami yaitu terbuat dari plat besi galvanis. Bentuk media Agami seperti papan balok tanpa tutup. Bahan besi dikreasikan menjadi sebuah miniatur kenampakan alam yang dapat digunakan pada kelas III SD untuk mempelajari materi tema 3 subtema 4 pembelajaran ke 4, 5, dan 6. Media Agami didesain dengan tampilan yang menarik digunakan secara efektif dan efisien untuk siswa. Media Agami merupakan media interaksi karena menumbuhkan interaksi guru dan siswa. Pada media Agami juga dilengkapi 
dengan miniatur pendukung dari materi yang akan dijelaskan dalam pembelajaran tematik.

\section{Pembelajaran Tematik}

Pembelajaran tematik disusun membentuk sebuah tema yang telah ditentukan dan ditinjau kedalam berbagai mata pelajaran (Wahyuni et al., 2017). Pembelajaran tematik adalah pembelajaran berbentuk tema menghubungkan berbagai mata pelajaran agar memberikan sebuah pengalaman berkreativitas yang berharga untuk siswa (Muklis, 2012). Keuntungan bagi guru yaitu menghemat waktu karena pembelajaran tematik dapat dipersiapkan pada suatu tema dan meringankan beban guru (Meilina et al., 2020).

\section{Penelitian Terdahulu}

Beberapa peneliti telah
mengembangkan media miniatur sebagai media pembelajaran diantaranya oleh Hayati (2013), Ariyanti (2015), dan Hendratni (2016) yang mengembangkannya untuk diterapkan di SD. Hasil penelitian tersebut menunjukkan bahwa siswa lebih tertarik dalam proses belajar mengajar ketika guru menggunakan media miniatur dalam pembelajaran (Hayati, 2013; Ariyanti, 2015; Hendratni, 2016). Penelitian lain oleh Kusumaningrum \& Widyawati (2019) menunjukkan bahwa pembelajaran tematik menggunakan media miniatur dapat meningkatkan keterlibatan siswa dalam belajar.

\section{METODE PENELITIAN}

Jenis penelitian ini yaitu penelitian dan pengembangan (R\&D). Model yang digunakan berpedoman pada Borg dan Gall. Langkahlangkah terdapat pada penelitian ada 10 yaitu potensi dan masalah, pengumpulan data, desain produk, validasi desain, revisi desain, ujicoba produk, revisi produk, ujicoba pemakaian, revisi produk, dan produk masal (Sugiyono, 2016). Penelitian dan pengembangan media Agami ini hanya dilakukan hingga tahap ke-7 yaitu potensi dan masalah, pengumpulan data, desain produk, validasi desain, revisi desain, ujicoba produk, dan revisi produk. Kegiatan pada tahap berikutnya tidak dilakukan karena keterbatasan sumber daya dan kemampuan peneliti.

Pada tahap awal penelitian dilakukan pada semester ganjil tahun pelajaran 2018 di tiga SD yang terdapat di Kecamatan Talun, Kecamatan Nglegok, dan Kecamatan Doko. Penelitian awal dilakukan untuk menggali semua permasalahan yang meliputi observasi, wawancara, dan memberikan angket. Instrumen yang digunakan yaitu lembar wawancara ditujukan pada guru kelas III SD, angket terbuka, angket tertutup untuk siswa kelas III SD. Desain produk diperoleh dari hasil observasi di tiga sekolah dasar di kabupaten Blitar bahwa dibutuhkan media pembelajaran untuk tema benda di sekitarku kelas III SD.

Angket yang digunakan pada penelitian ini berupa kelayakan media dan kualitas media Agami. Kelayakan media diukur dari penilaian angket validasi ahli meliputi tiga ahli media yang berpengalaman dalam menyusun media pembelajaran, tiga ahli materi yang berpengalaman dalam materi pembelajaran tematik, dan tiga ahli bahasa yang berpengalaman dalam bidang studi bahasa. Kualitas media Agami diukur dari penilaian angket respon siswa sebanyak 12 siswa untuk diisi dengan jujur mengenai media Agami serta dokumentasi untuk memperkuat data.

Instrumen yang digunakan untuk mengumpulkan data yaitu angket validasi ahli untuk mengukur kelayakan media Agami. Angket respon siswa untuk mengukur kualitas media. Adapun Langkah-langkah Borg dan Gall dalam penelitian ini dapat dilihat pada Gambar 1. 
ISSN : 2303-1514 | E-ISSN : 2598-5949

POTENSI DAN MASALAH

Observasi dilakukan pada tiga SD di kabupaten Blitar diperoleh data:

- Guru hanya menerapkan metode ceramah.

- Media digunakan hanya papan tulis.

- Siswa kurang mampu menguasai materi yang diajarkan.

\section{PENGUMPULAN DATA}

- Observasi dilakukan pada saat proses pembelajaran. - Wawancara ditujukan pada guru kelas III SD diperoleh hasil bahwa guru menggunakan metode ceramah, bahan ajar pendukungnya yaitu buku guru tematik kelas III SD, dan media penunjang menggunakan papan tulis.

- Angket yang diberikan yaitu angket terbuka dan angket tertutup.

\section{VALIDASI DESAIN}

- Validasi media ada tiga ahli media pengalaman dalam menyusun media pembelajaran.

- Validasi materi ada tiga ahli materi yang berpengalaman dalam pembelajaran tematik.

- Validasi bahasa ada tiga ahli bahasa yang berpengalaman dalam studi bahasa.

\section{DESAIN PRODUK}

Hasil pengumpulan data diperoleh bahwa dibutuhkan media pembelajaran pada tema benda disekitarku subtema keajaiban perubahan wujud di sekitar yang kreatif, efektif, dan efisien.

REVISI DESAIN
- Validasi media dilakukan hingga dinyatakan
valid oleh ketiga ahli media.
- Validasi materi dilakukan hingga dinyatakan
valid oleh ketiga ahli materi.
- Validasi Bahasa dilakukan hingga dinyatakan
valid oleh ketiga ahli bahasa.

\section{UJI COBA PRODUK}

Dilakukan pada SD yang berada diKecamatan Doko untuk siswa kelas III SD sebanyak 12 siswa. Pada ujicoba produk, masing-masing siswa diberikan angket respon siswa untuk diisi secara jujur tentang media Agami.

REVISI PRODUK
Tahap ini dilakukan perbaikan pada media
Agami agar dapat digunakan dengan baik
dalam pembelajaran tematik khususnya
tema benda di sekitarku.

\section{Gambar 1. Langkah-langkah Borg dan Gall dalam Penelitian}

Teknik analisis data berupa kuantitatif yang menggunakan kriteria pencapaian keberhasilan didapatkan dari kriteria minimal 61-80\% dengan kategori layak. Skor yang didapatkan dari kelayakan oleh para ahli dirumuskan sebagai berikut: Hasil $=\frac{\text { total yang diperoleh }}{\text { skor maksimum }} \times 100 \%$

Kategori kelayakan berdasarkan kriteria sebagai berikut: 
Tabel 1. Kriteria Kelayakan Media

\begin{tabular}{ccll}
\hline No. & Skor dalam persen & Kategori Kelayakan \\
\hline 1. & $<21 \%$ & Sangat Tidak Layak \\
2. & $21-40 \%$ & Tidak Layak \\
3. & $41-60 \%$ & Cukup Layak \\
4. & $61-80 \%$ & Layak \\
5. & $81-100 \%$ & Sangat Layak \\
\hline
\end{tabular}

Sumber: Arikunto (2009)

Angket validasi terdapat tiga ahli bidang terdiri dari media, materi, dan bahasa. Validator ahli media ada tiga yaitu dua dosen Universitas Islam Balitar dengan jenjang minimal S2 pengalaman 2 tahun dan satu guru kelas III Sekolah Dasar lulusan PGSD dengan jenjang minimal S1 pengalaman 2 tahun. Kisikisi instrumen media dapat dilihat pada Tabel 2.

Tabel 2. Kisi-kisi Instrumen Media

\begin{tabular}{clc}
\hline No. & \multicolumn{1}{c}{ Indikator } & Pernyataan \\
\hline 1. & Isi materi dalam media Agami. & $1,2,3,4,5$ \\
2. & Desain media Agami. & $6,7,8,9,10$ \\
3. & Penilaian secara keseluruhan media Agami. & $11,12,13,14,15$ \\
\hline
\end{tabular}

Validator ahli materi ada tiga yaitu dua dosen jurusan PGSD Universitas Islam Balitar dengan jenjang pendidikan minimal S2 pengalaman 2 tahun dan satu guru kelas III
Sekolah Dasar lulusan PGSD dengan jenjang minimal S1 pengalaman 2 tahun. Kisi-kisi instrumen materi dapat dilihat pada Tabel 3.

Tabel 3. Kisi-kisi Instrumen Materi

\begin{tabular}{clc} 
No. & \multicolumn{1}{c}{ Indikator } & Pernyataan \\
\hline 1. & Kesesuaian materi pada media Agami. & $1,2,3,4,5$ \\
2. & Isi materi pembelajaran. & 6 \\
3. & Isi soal pada media Agami. & 7 \\
4. & Penilaian keseluruhan pada media Agami. & 8 \\
\hline
\end{tabular}

Validator ahli bahasa ada tiga yaitu dua ahli bahasa minimal S2 pengalaman 2 tahun dan guru kelas III Sekolah Dasar lulusan
PGSD dengan jenjang minimal S1 pengalaman 2 tahun. Kisi-kisi instrumen bahasa dapat dilihat pada Tabel 4.

Tabel 4. Kisi-kisi Instrumen Bahasa

\begin{tabular}{clc}
\hline No. & \multicolumn{1}{c}{ Indikator } & Pernyataan \\
\hline 1. & Kesesuaian bahasa dalam media Agami. & $1,2,3,4,5,6,7$ \\
2. & Penilaian keseluruhan bahasa dalam media & Agami. \\
\hline
\end{tabular}

\section{HASIL DAN PEMBAHASAN}

Hasil penelitian dan pengembangan media Agami meliputi potensi dan masalah, pengumpulan data, desain produk, validasi desain, revisi desain, ujicoba produk, dan revisi produk. Berdasarkan observasi awal di 3 sekolah SD/MI di Blitar melalui pemberian angket dan wawancara kepada siswa dan guru didapatkan informasi bahwa guru mempelajari tema 3 benda di sekitarku subtema 4 keajaiban perubahan wujud di sekitarku dengan menerapkan metode ceramah, bahan ajar buku 
tematik, dan media penunjang menggunakan papan tulis. Dampak keterbatasan dari media pembelajaran yang ada pada sekolah antara lain siswa ada yang sudah memahami materi ada juga yang belum dapat memahami materi. Menurut permasalahan diatas, maka memerlukan adanya media pembelajaran yang mampu membuat siswa aktif saat pembelajaran berlangsung. Peneliti mengembangkan media Agami tema benda di sekitarku untuk siswa kelas III SD.

Desain produk menggunakan cara mengumpulkan alat dan bahan. Pembuatan desain awal dengan menentukan tema dan materi yang akan digunakan. Membuat buku petunjuk penggunaan media Agami tema 3 subtema 4 kelas III Sekolah Dasar. Bahan terkumpul selanjutnya dilakukan pembuatan papan balok tanpa tutup dengan bahan utama dari plat besi galvanis yang ukurannya telah ditentukan. Membuat kaki pada keempat sudut papan dan diberi roda. Pada papan bagian dalam, beri sekatan di sebelah kanan dengan ukuran $25 \mathrm{~cm}$ dan catlah dengan warna biru muda. Pada bagian sebelah kiri yang memiliki ukuran $65 \mathrm{~cm}$ diberi kayu dan dilapisi dengan semen yang telah dicampur menggunakan potongan koran hingga penuh. Pada bagian samping kanan, kiri, dan belakang papan, pasang akrilik. Disisi belakang tempelkan gambar background pemandangan. Papan siap diisi dengan bahan-bahan miniatur dan dibentuk sebagus mungkin sehingga menarik untuk digunakan dan dilihat. Produk yang sudah jadi selanjutnya adalah memvalidasikan kepada para validator sebanyak 9 orang yang meliputi 3 orang ahli media, 3 orang ahli materi, dan 3 orang ahli bahasa. Berikut adalah gambar media Agami dapat dilihat pada Gambar 2.

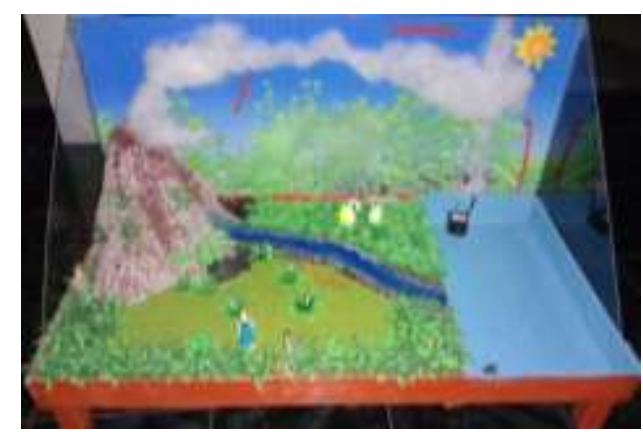

Gambar 2. Media Agami

Komponen penilaian media yaitu isi materi dalam media Agami, desain media Agami, dan penilaian secara keseluruhan media Agami. Penilaian dari validator media ditunjukkan pada Tabel 5.

Tabel 5. Rekapitulasi Perolehan Skor Validasi Media

\begin{tabular}{|c|c|c|c|c|c|c|}
\hline \multirow[b]{2}{*}{ Aspek Pengukuran } & \multicolumn{3}{|c|}{ Penilaian } & \multirow[b]{2}{*}{ Total } & \multirow[b]{2}{*}{$\begin{array}{c}\text { Total } \\
\text { Keseluruhan }\end{array}$} & \multirow[b]{2}{*}{ Persentase } \\
\hline & $\begin{array}{c}\text { Validator } \\
1\end{array}$ & $\begin{array}{l}\text { Validator } \\
2\end{array}$ & $\begin{array}{c}\text { Validator } \\
3\end{array}$ & & & \\
\hline $\begin{array}{l}\text { Isi materi dalam media } \\
\text { Agami. }\end{array}$ & 20 & 20 & 20 & 60 & 60 & $100 \%$ \\
\hline Desain media Agami. & 17 & 18 & 20 & 55 & 60 & $91.6 \%$ \\
\hline $\begin{array}{l}\text { Penilaian secara } \\
\text { keseluruhan media Agami. }\end{array}$ & 17 & 17 & 18 & 52 & 60 & $86.6 \%$ \\
\hline Jumlah Skor Total & 54 & 55 & 58 & 167 & 180 & $278.2 \%$ \\
\hline $\begin{array}{l}\text { Persentase Rata-Rata } \\
\text { Kriteria }\end{array}$ & & & & & & \\
\hline
\end{tabular}




\section{PRIMARY: JURNAL PENDIDIKAN GURU SEKOLAH DASAR VOLUME 10 NOMOR 5 OKTOBER 2021 \\ ISSN : 2303-1514 | E-ISSN : 2598-5949 \\ DOI : http://dx.doi.org/10.33578/jpfkip.v10i5.8234 \\ https://primary.ejournal.unri.ac.id/index.php/JPFKIP}

Berdasarkan rekapitulasi perolehan skor validasi media mendapatkan total 167 dengan persentase rata-rata $92.7 \%$ dengan "Layak". Isi materi dalam media Agami sebesar 100\% dengan kriteria "Layak". Aspek desain media Agami mencapai persentase sebesar $91.6 \%$ dengan kriteria "Layak". Aspek penilaian secara keseluruhan media Agami mencapai persentase sebesar $86.6 \%$ dengan kriteria "Layak". Berikut adalah hasil pengembangan produk media Agami dapat dilihat pada Gambar 3. dan Gambar 4.

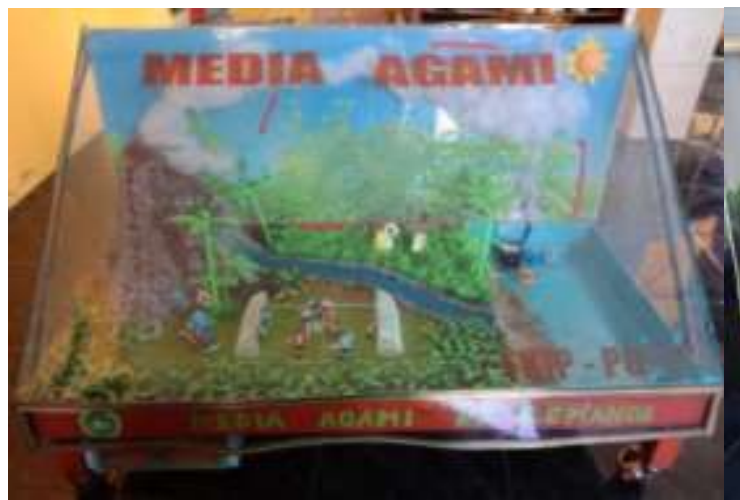

Gambar 3. Tampak Depan

Komponen penilaian ahli materi yaitu kesesuaian materi pada media Agami, isi materi pembelajaran, isi soal pada media

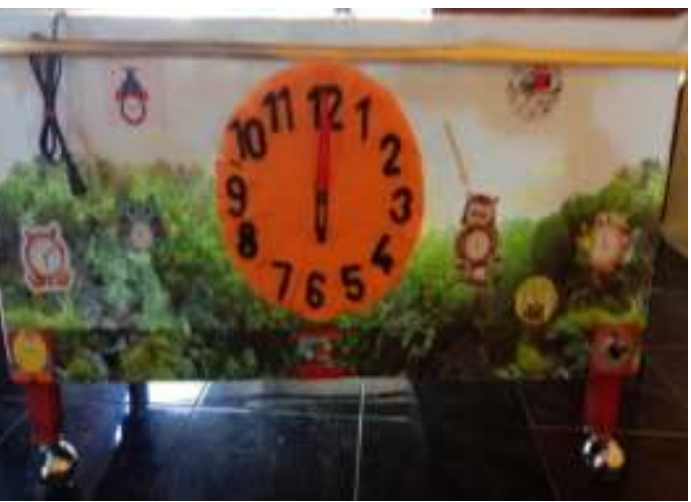

Gambar 4. Tampak Belakang

Tabel 6. Rekapitulasi Perolehan Skor Validasi Materi

\begin{tabular}{lcccccc}
\hline \multicolumn{1}{c}{$\begin{array}{c}\text { Aspek } \\
\text { Pengukuran }\end{array}$} & $\begin{array}{c}\text { Validator } \\
\mathbf{1}\end{array}$ & $\begin{array}{c}\text { Validator } \\
\mathbf{2}\end{array}$ & $\begin{array}{c}\text { Validator } \\
\mathbf{3}\end{array}$ & Total & $\begin{array}{c}\text { Total } \\
\text { Keseluruhan }\end{array}$ & Persentase \\
\hline $\begin{array}{l}\text { Kesesuaian materi } \\
\text { pada media Agami. }\end{array}$ & 20 & 19 & 20 & 59 & 60 & $98.3 \%$ \\
$\begin{array}{l}\text { Isi materi } \\
\text { pembelajaran. }\end{array}$ & 4 & 4 & 4 & 12 & 12 & $100 \%$ \\
$\begin{array}{l}\text { Isi soal pada media } \\
\text { Agami. }\end{array}$ & 4 & 4 & 4 & 12 & 12 & $100 \%$ \\
$\begin{array}{l}\text { Penilaian } \\
\text { keseluruhan pada } \\
\text { media Agami. }\end{array}$ & 4 & 4 & 4 & 12 & 12 & $100 \%$ \\
\hline $\begin{array}{l}\text { Jumlah Skor } \\
\text { Total }\end{array}$ & $\mathbf{3 2}$ & $\mathbf{3 1}$ & $\mathbf{3 2}$ & $\mathbf{9 5}$ & $\mathbf{9 6}$ & $\mathbf{3 9 8 . 3 \%}$ \\
$\begin{array}{l}\text { Persentase Rata- } \\
\begin{array}{l}\text { Rata } \\
\text { Kriteria }\end{array}\end{array}$ & & & $\begin{array}{l}\mathbf{9 8 . 9 \%} \\
\text { Layak }\end{array}$ & & & \\
\hline
\end{tabular}

Berdasarkan rekapitulasi perolehan skor validasi materi menunjukkan bahwa kesesuaian materi pada media Agami adalah 98.3\% dengan kriteria "Layak". Aspek isi materi pembelajaran, aspek isi soal pada media Agami, dan penilaian keseluruhan pada media Agami adalah 100\% dengan kriteria "Layak".
Agami, dan penilaian keseluruhan pada media Agami. Pengukuran dari validator materi disajikan dalam Tabel 6. 
ISSN : 2303-1514 | E-ISSN : 2598-5949

Agami. Pengukuran dari validasi bahasa

ditunjukkan pada Tabel 7.

Tabel 7. Rekapitulasi Perolehan Skor Validasi Bahasa

\begin{tabular}{|c|c|c|c|c|c|c|}
\hline \multirow[b]{2}{*}{ Aspek Pengukuran } & \multicolumn{3}{|c|}{ Penilaian } & \multirow[b]{2}{*}{ Total } & \multirow{2}{*}{$\begin{array}{c}\text { Total } \\
\text { Keseluruhan }\end{array}$} & \multirow[b]{2}{*}{ Persentase } \\
\hline & $\begin{array}{c}\text { Validator } \\
1\end{array}$ & $\begin{array}{c}\text { Validator } \\
2\end{array}$ & $\begin{array}{c}\text { Validator } \\
\mathbf{3}\end{array}$ & & & \\
\hline $\begin{array}{l}\text { Kesesuaian bahasa } \\
\text { dalam media Agami. } \\
\text { Penilaian }\end{array}$ & 25 & 26 & 28 & 79 & 84 & $94 \%$ \\
\hline $\begin{array}{l}\text { keseluruhan bahasa } \\
\text { dalam media Agami. }\end{array}$ & 11 & 11 & 12 & 34 & 36 & $94,4 \%$ \\
\hline Jumlah Skor Total & 36 & 37 & 40 & 113 & 120 & $188.4 \%$ \\
\hline $\begin{array}{l}\text { Persentase Rata- } \\
\text { Rata }\end{array}$ & \multicolumn{6}{|c|}{$94.1 \%$} \\
\hline Kriteria & \multicolumn{6}{|c|}{ Layak } \\
\hline
\end{tabular}

Hasil validasi oleh tiga validator bahasa diperoleh skor 113 dengan persentase $94.1 \%$ dikatakan "Layak". Aspek kesesuaian bahasa dalam media Agami mencapai persentase 94\% sedangkan aspek penilaian keseluruhan bahasa dalam media Agami sebesar 94.4\%. Revisi yang perlu diperbaiki pada materi gambar yaitu menyesuaikan pada media Agami. Pada buku petunjuk ditambahkan cara penggunaan.
Berdasarkan dari kesembilan validator, diketahui bahwa media Agami dikategorikan layak untuk digunakan pembelajaran. Rata-rata persentase media Agami sebesar 95.2\% dan layak sebagai media pembelajaran untuk kelas III Sekolah Dasar. Hasil validasi dari validator ahli media, materi, dan bahasa terangkum pada Tabel 8.

Tabel 8. Rangkuman Hasil Validasi dari Validator Media, Materi, dan Bahasa

\begin{tabular}{llc}
\hline \multicolumn{1}{c}{ No. } & Ahli Bidang & Persentase \\
\hline 1. & Media & $92.7 \%$ \\
2. & Materi & $98.8 \%$ \\
3. & Bahasa & $94.1 \%$ \\
\hline Rata-rata & $95.2 \%$ \\
Kategori & Layak \\
\hline
\end{tabular}

Tahap selanjutnya yaitu uji coba respon siswa menggunakan 12 subyek uji coba siswa dari kelas III untuk mengetahui respon siswa terhadap penggunaan media Agami. Siswa mengisi angket respon siswa setelah melakukan pengamatan dan penggunaan media Agami untuk pembelajaran tematik. Menurut hasil respon siswa dapat ditarik kesimpulan bahwa media Agami menyenangkan, siswa bersungguh-sungguh mengikuti pelajaran, materi yang disampaikan mudah dipahami, dan setelah mengikuti pelajaran menggunakan media Agami siswa merasa senang karena medianya bagus dan menarik. Tanggapan yang diberikan siswa membuktikan bahwa media Agami memperoleh respon baik dan layak untuk pembelajaran tematik. Selain itu, media Agami dapat digunakan sebagai acuan untuk produksi serta pengembangan media pembelajaran selanjutnya. Adapun perolehan angket respon siswa ditunjukkan pada Tabel 9. 
Tabel 9. Angket Respon Siswa

\begin{tabular}{cccccccccc}
\hline \multirow{2}{*}{ Siswa } & \multicolumn{3}{c}{$\begin{array}{c}\text { Ketertarikan Media } \\
\text { Agami }\end{array}$} & \multicolumn{3}{c}{$\begin{array}{c}\text { Materi dan Motivasi } \\
\text { Siswa }\end{array}$} & $\begin{array}{c}\text { Bahasa } \\
\text { dalam Media } \\
\text { Agami }\end{array}$ & Skor \\
\cline { 2 - 8 } & $\mathbf{1}$ & $\mathbf{2}$ & $\mathbf{3}$ & $\mathbf{4}$ & $\mathbf{5}$ & $\mathbf{6}$ & $\mathbf{7}$ & $\mathbf{8}$ & \\
\hline 1 & 1 & 1 & 1 & 1 & 1 & 1 & 1 & 0 & 7 \\
2 & 1 & 1 & 1 & 1 & 1 & 1 & 1 & 1 & 8 \\
3 & 1 & 1 & 1 & 1 & 1 & 1 & 1 & 1 & 8 \\
4 & 1 & 1 & 1 & 1 & 1 & 1 & 1 & 1 & 8 \\
5 & 1 & 0 & 1 & 1 & 1 & 1 & 0 & 1 & 6 \\
6 & 1 & 1 & 1 & 1 & 1 & 1 & 1 & 1 & 8 \\
7 & 1 & 1 & 0 & 1 & 1 & 1 & 0 & 1 & 6 \\
8 & 1 & 1 & 1 & 1 & 1 & 1 & 1 & 0 & 7 \\
9 & 1 & 1 & 1 & 1 & 1 & 1 & 1 & 1 & 8 \\
10 & 1 & 1 & 1 & 1 & 1 & 1 & 1 & 1 & 8 \\
11 & 1 & 1 & 1 & 1 & 1 & 1 & 1 & 1 & 8 \\
12 & 1 & 1 & 1 & 1 & 1 & 1 & 1 & 1 & 8 \\
Total & & & & & & & & & 90 \\
Maksimal & & & & & & & & & 96 \\
Persentase & & & & & & & & & $93.75 \%$ \\
\hline
\end{tabular}

Berdasarkan Tabel 8. hasil respon siswa setelah menggunakan media Agami, mendapatkan hasil sebesar $93.75 \%$. Pada angket respon yang dilakukan peneliti, didapatkan nilai sangat layak dan sesuai dengan siswa. Siswa dapat menggunakan media Agami dengan baik dibuktikan dari siswa mampu mempraktikkan media Agami secara urut.

\section{Pembahasan}

Berdasarkan hasil penelitian pengembangan media Agami, penilaian kelayakan mendapatkan $95.2 \%$ dengan kategori layak digunakan sebagai media pembelajaran khususnya pembelajaran tematik. Keadaan ini sesuai dengan penelitian (Ramli, 2017) bahwa miniatur dapat dikatakan layak dan memiliki kualitas tinggi untuk dijadikan media pembelajaran karena siswa kelas III SD membutuhkan media yang konkret untuk materi kenampakan alam.

Media Agami berbasis miniatur sangat cocok untuk siswa kelas III SD dengan hasil respon siswa sebesar $93.75 \%$ dengan kriteria sangat layak karena sesuai karakter siswa senang dengan hal baru terutama pada pengamatan benda secara konkret dapat membantu siswa memahami materi perubahan wujud benda. Media Agami mempunyai keunggulan yang dilengkapi dengan peraga siklus air yang dapat menampilkan proses siklus air dengan nyata karena pada penelitian terdahulu miniatur air hanya gambar air saja sehingga hanya untuk menampilkan pemahaman pada indera mata tanpa adanya penjelasan secara langsung. Karakter siswa kelas III Sekolah Dasar adalah tingginya rasa ingin tahu, senang bermain, suka memperhatikan hal baru, dan tetap berprestasi (Sumantri \& Permana, 2001). Tahap operasional konkret yang ada pada siswa kelas III Sekolah Dasar mengutamakan guru harus menggunakan alat peraga ketika pembelajaran berlangsung karena melalui alat peraga diharapkan siswa dapat mengikuti pembelajaran dengan baik (Ramlah, 2015). Menurut teori Vygotsky tentang perkembangan kognitif didapatkan dari hasil interaksi individu dengan individu lain agar pemikiran matematika anak dapat berkembang baik (Danoebroto, 2015).

Kelebihan media Agami yaitu dapat digunakan untuk pembelajaran tematik yang mencakup empat mata pelajaran yaitu Bahasa Indonesia, PPKn, PJOK, dan Matematika 
karena pada pembelajaran tematik harus memuat beberapa mata pelajaran yang dijadikan satu. Pada mata pelajaran Bahasa Indonesia tentang materi terjadinya hujan terletak dibagian miniatur matahari yang menyinari miniatur laut kemudian air menguap menjadi miniatur awan menggumpal menjadi satu membentuk hujan, hujan turun di miniatur bukit lalu air kembali lagi ke miniatur laut. Mata pelajaran PPKn tentang rasa tolong menolong digambarkan pada miniatur PMI (Palang Merah Indonesia) ketika ada pemain bola yang cidera langsung ditolong untuk diberi P3K (Pertolongan Pertama Pada Kecelakaan). Mata pelajaran PJOK tentang menggiring bola digambarkan dengan miniatur sepak bola yang menggiring bola ke gawang lawan. Matematika tentang hitungan waktu dapat dijelaskan pada media Agami bagian belakang terdapat miniatur jam yang dilengkapi dengan angka dan jarum jam sebagai penunjuk waktu. Selain itu, media pembelajaran Agami terbuat dari bahan yang berkualitas yaitu terbuat dari plat besi galvanis. Plat besi galvanis merupakan bahan utama pada media Agami yang dapat tahan lama dan tidak rusak jika terkena air. Penelitian ini didukung oleh (Pangaribuan, 2014) mengungkapkan bahwa pemilihan material baja ringan yang kuat sebagai alternatif pengganti bahan kayu agar ramah lingkungan. Media Agami didalamnya menayangkan air sehingga dapat dilihat secara konkret proses jalannya air.

\section{SIMPULAN DAN REKOMENDASI}

Media Agami mendapatkan nilai ratarata sebesar $95.2 \%$ pada hasil penilaian ketiga validator yaitu media, materi, dan bahasa dengan kriteria layak digunakan pada pembelajaran tema benda di sekitarku untuk siswa kelas III SD. Respon siswa terhadap media Agami diperoleh persentase sebanyak 93.75\% dengan kriteria layak. Media Agami dapat menumbuhkan ketertarikan dan respon siswa untuk mengikuti pembelajaran di kelas, sehingga media Agami layak sebagai penunjang pembelajaran untuk tema benda disekitarku.

Rekomendasi dari penelitian ini masih diterapkan pada satu kelas untuk uji coba kelompok kecil. Penelitian yang telah dikembangkan ini perlu dilanjutkan sampai tahap ke 10 dari Borg and Gall. Peneliti mengharapkan agar media Agami dikembangkan lagi oleh para ahli berikutnya untuk mencapai tujuan pendidikan yang baik dan mengetahui efektifitas media Agami terhadap hasil belajar siswa.

\section{DAFTAR PUSTAKA}

Akbar, S. (2015). Instrumen Perangkat Pembelajaran (H. Anwar (ed.); cetakan ke). PT. Remaja Rosdakarya Offset.

Anggraini, N. A. R. I. (2019). Pengembangan Media Miniatur Alam Sekitar Pada Materi Menulis Puisi Siswa Kelas V SDN 2 Suralaga Tahun Ajaran 2015/2016. JISIP (Jurnal Ilmu Sosial Dan Pendidikan), 3(1), 12-20.

Arikunto, S., \& Safruddin, A. J. (2009). Evaluasi Program Pendidikan. Bandung: Bumi Aksara.

Ariyanti, H. A. (2015). Pengembangan Media Pembelajaran MIBI (Miniatur Budaya Indonesia) Tema Indahnya Kebersamaan Kelas IV SD N Kepatihan. Jurnal Pendidikan Guru Sekolah Dasar, 4(2), 20-35.

Arsyad, A. (2014). Media Pembelajaran. Jakarta: Raja Grafindo Persada.

Asyhar, R. (2012). Kreatif Mengembangkan Media Pembelajaran. Jakarta: Referensi.

Baharuddin, B. (2016). Penggunaan Alat Peraga dengan Pembelajaran Langsung dalam Meningkatkan Motivasi Mengajar Guru di SMPN 2 Kubu Kabupaten Rokan Hilir. Primary: Jurnal Pendidikan Guru Sekolah Dasar, 5(3), 700-712.

Danoebroto, S. W. (2015). Teori Belajar Konstruktivis Piaget dan Vygotsky. Indonesian Digital Journal of Mathematics and Education, 2(3), 191198. 
Hayati, H. (2013). Penggunaan Media Miniatur Binatang dan Tumbuhan untuk Meningkatkatkan Proses Pembelajaran Tematik di Sekolah Dasar. Jurnal Penelitian Pendidikan Guru Sekolah Dasar, 1(2), 1-10.

Hendratni, R. W. (2016). Pengembangan Media Pembelajaran Bangun Datar Berbasis Miniatur Rumah Pada Mata Pelajaran Matematika SD. Prodi PGSD $U P Y$.

Khairi, Z. (2012). Efektivitas Media Maket Sebagai Representasi Karya Perancangan Arsitektur di Era Digital. Jakarta: FT UI.

Komala, R., Suryanda, A., \& Lismana, D. D. (2016). Pengembangan Paludarium sebagai Media Pembelajaran Biologi Pokok Bahasan Ekosistem di SMA. Biosfer: Jurnal Pendidikan Biologi, 9(1), $10-14$.

Kusumaningrum, D., \& Widyawati, T. (2019). Penerapan Media Miniatur untuk Meningkatkan Partisipasi Siswa Kelas IV Tema 8 Sub Tema 1 SDN 2 Permanu Pakisaji Malang Tahun Ajaran 2018/2019. Jurnal Pendidikan Dasar Perkhasa: Jurnal Penelitian Pendidikan Dasar, 5(2), 133-144.

Meilina, F., Surahman, F., \& Sari, M. (2020). Pengembangan Media Pembelajaran Berbentuk Miniatur Rumah Adat Pada Tema 7 Untuk Siswa Kelas IV SDN 002 Tebing Kabupaten Karimun. Jurnal Minda, 2(1), 44-51.

Miarso, Y. (2004). Menyemai Benih Teknologi Pendidikan. Jakarta: Prenoda Media.

Muklis, M. (2012). Pembelajaran Tematik. Fenomena, 4(1), 20-30.

Nana, S., \& Ahmad, R. (2015). Media Pengajaran. Jakarta: Sinar Baru Algensindo.

Pangaribuan, M. R. (2014). Baja Ringan Sebagai Pengganti Kayu Dalam Pembuatan Rangka Atap Bangunan
Rumah Masyarakat. Palembang: Sriwijaya University.

Ramlah, R. (2015). Penerapan Teori Perkembangan Mental Piaget Tahap Operasional Konkret Pada Hukum Kekekalan Materi. Judika (Jurnal Pendidikan Unsika), 3(2), 30-40.

Ramli, I. (2017). Pengembangan Media Konvensional Miniatur Kenampakan Alam Subtema Keindahan Alam Negeriku untuk Siswa Kelas Empat (IV) Sekolah Dasar. Skripsi. Yogyakarta: Universitas Shanata Dharma Yogyakarta.

Sugiyono. (2016). Metode penelitian pendidikan:(pendekatan kuantitatif, kualitatif dan $R \& D$ ). Jakarta: Alfabeta.

Sumantri, M., \& Permana, J. (2001). Strategi Belajar Mengajar. Bandung: CV Maulana.

Wahyuni, H. T., Setyosari, P., \& Kuswandi, D. (2017). Implementasi pembelajaran tematik kelas 1 SD. Edcomtech Jurnal Kajian Teknologi Pendidikan, 1(2), 129136.

Widiyatmono, A. F. (2014). Efektivitas Pelaksanaan Praktikum Anatomi Hewan Di Laboratorium Biologi Ditinjau Dari Nilaipraktikum. Surakarta: Universitas Muhammadiyah Surakarta. 